\title{
An Assessment of Hurricane Charley's Impact on Cuba ${ }^{1}$
}

William A. Messina, Jr. ${ }^{2}$

\section{Background}

Just after midnight on Friday, August 13, 2004 (Fidel Castro's 78th birthday), Hurricane Charley struck the island nation of Cuba. The storm had reached hurricane strength just south of Jamaica on Wednesday, August 11th, and came ashore on the southern shoreline of western Cuba between the towns of Batabanó and Guanimar (Figure 1, http://www.nhc.noaa.gov/ftp/graphics/AT03/refresh/ AL0304S+GIF/152158S.gif). The storm traveled north-northwest across the narrowest part of the island passing almost directly over the capital city of Havana. Hurricane Charley moved off the coastline of Cuba about two hours later at approximately 2:00 a.m., with the eye of the storm exiting near the communities of Baracoa and Mariel approximately 15 miles west of downtown Havana.

Reports and information from Cuba on the damage from Hurricane Charley have been limited. However, in an effort to be responsive to inquiries about storm damage in Cuba, this report attempts to compile the limited amount of information that is available from the press and through personal communication with colleagues in Cuba with knowledge of Cuba's economy and agricultural sector, developed over the past 10 years of research on Cuba conducted by the University of Florida's Institute of Food and Agricultural Sciences (UF/IFAS) Food and Resource Economics Department, to offer our assessment of the situation in Cuba following Hurricane Charley.

\section{General Information}

Hurricane Charley was a Category Two storm on the Saffir-Simpson Hurricane Scale when it struck Cuba (for detail on the Saffir-Simpson Hurricane Scale go to the U.S. National Hurricane Center website at http://www.nhc.noaa.gov/aboutsshs.shtml). Category Two storms include sustained winds of between 96 and 110 miles per hour (mph), or 154-177 kilometers per hour. Officials from Cuba's meteorological service reported wind gusts from Hurricane Charley as high as $125 \mathrm{mph}$, with sustained winds of 105 $\mathrm{mph}$. This was reported to be the strongest hurricane to strike Havana Province and the city of Havana since 1915.

In addition to the potential physical and structural damage from the wind and rain associated with a hurricane of this magnitude, Category Two storms also typically can produce large storm surges in coastal areas. Therefore, it is not surprising that initial press reports indicated that the storm caused

1. This is EDIS document FE494, a publication of the Department of Food and Resource Economics, Florida Cooperative Extension Service, UF/IFAS, University of Florida, Gainesville, FL. Published September 2004. Please visit the EDIS website at http://edis.ifas.ufl.edu.

2. William A. Messina, Jr., Coordinator of Economic Analysis, Department of Food and Resource Economics, Florida Cooperative Extension Service, UF/IFAS, University of Florida, Gainesville, FL.

The Institute of Food and Agricultural Sciences is an equal opportunity/affirmative action employer authorized to provide research, educational information and other services only to individuals and institutions that function without regard to race, color, sex, age, handicap, or national origin. For information on obtaining other extension publications, contact your county Cooperative Extension Service office. Florida Cooperative Extension Service/Institute of Food and Agricultural Sciences/University of Florida/Christine Taylor Waddill, Dean. 


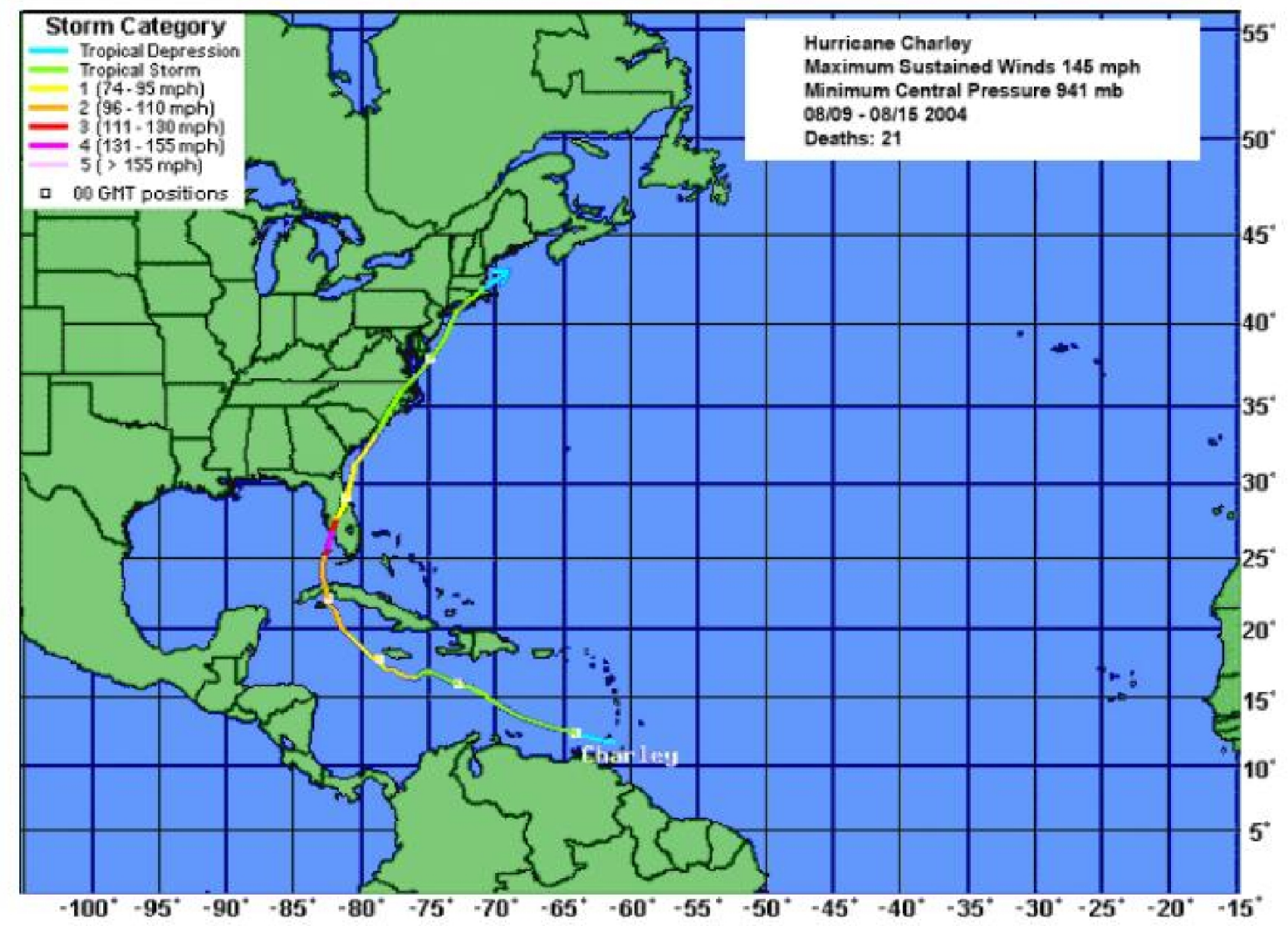

substantial damage. On August 25th, the official Cuban government press placed damage estimates at more than $\$ 1$ billion.

Cuba has proactive storm preparation procedures and the government's National Information Agency reported that 150,000 people were evacuated from areas prone to flooding in western and central Cuba. An additional 47,000 people were evacuated from old and unstable buildings in the colonial area in the city of Havana and 1,800 were evacuated on the sparsely populated Isle of Youth to safer locations on the island. Reports indicated that upwards of 2,000 tourists were evacuated from the resort island of Key Largo off Cuba's south coast and various other resort areas. As a result of these evacuation programs and the actions of Cuba's well-organized Civil Defense system, loss of life in Cuba from Hurricane Charley was limited to five casualties: three deaths in collapsed buildings, one death from a tree which fell on a home, and one drowning.

\section{Infrastructure}

Cuba's infrastructure is generally in poor condition as the result of 45 years of inadequate maintenance. (For example, even under normal conditions, building collapses in the city of Havana are not uncommon because of deteriorating foundations.) Damage to all types of infrastructure from Hurricane Charley therefore is expected to be significant in the city of Havana and the smaller towns and rural areas over which the storm passed.

\section{Public Utility Systems}

Prior to Hurricane Charley's arrival, the Cuban government cut off electrical service to prevent accidents and damage to electrical systems from power surges and intermittent service. This was a very wise precaution because damage to the power grid in the city of Havana, Havana Province, and Pinar del Rio Province to the west was very substantial. In addition to many miles of wires and nearly 1,500 power poles brought down by falling trees and wind, Hurricane Charley knocked down 28 
large, high tension (high voltage) wire towers at a power plant outside the town of Mariel, which supplied power to both Havana and Pinar del Rio Provinces. This has compounded the problems from electrical shortages Cuba has been experiencing since May, when a power plant in Matanzas Province (to the east of Havana Province) had to be shut down because of maintenance problems.

While electrical power is gradually being restored in the city of Havana, outages in rural areas likely will take longer to repair. A report from the Cuban press stated that 12 days after the storm less than half the consumers in Havana Province had electrical power. News reports from other sources indicate that Pinar del Rio Province was totally without power for 11 days following the storm, when electrical service only gradually began to be restored. Even in areas where power has been restored, blackouts reportedly are still occurring for as much as seven or eight hours each day.

Perhaps an even more serious problem, however, is the lack of running water and water service resulting from the storm. Only about half of the wells supplying the city of Havana are reported to be in operation because of the electrical outages. Lack of power also ha prohibited the pumping of water from sources outside the city. A Reuters news service report indicated nearly 70 percent of the city of Havana still had no running water four days after the storm struck. This is proving to be a particularly difficult problem for the Cuban government. A number of the pumps are being converted to operate on truckmotors and generators, and water service is only gradually being restored. In the meantime, the Cuban government is attempting to meet short-term needs by distributing water in tanker trucks, with residents having to carry water in buckets from distribution areas to their homes.

Outages of gas for cooking also were reportedly widespread more than a week after the storm. A Cuban official reportedly acknowledged that it could be late October before all utilities services are restored to some remote towns and villages.

\section{Housing}

With each passing day, the number of homes and buildings in Cuba reported as damaged by Hurricane Charley is growing. On August 17th, the Cuban government press reported that more than 1,100 buildings had completely collapsed and another 1,800 had suffered partial collapses from the storm, while 9,000 homes had roof damage in the city of Havana and Havana Province alone. Another 5,000 homes were damaged outside of these regions. By August 20th, a report from the Cuban press indicated that Hurricane Charley had damaged or destroyed more than 20,000 homes and buildings and, by August 25th, the Cuban government press reported the figure to be at more than 70,000. Damage in some areas was devastating. For example, the Cuban government reported that in the fishing village of El Cajio on Cuba's south shore near where the hurricane made landfall only 10 of 300 homes were left standing.

Cuban government officials also report that in the city of Havana, Havana Province, and Pinar del Rio Province nearly 800 schools and educational centers and over 300 health centers were damaged by the storm.

\section{Airport, Port, and Industrial Facilities}

Havana International Airport was closed as Hurricane Charley approached, but it has resumed service despite reported damage to the control tower. The extent of additional damage to these airport facilities is not known. However, it should be noted that Orlando International Airport sustained quite extensive damage from Hurricane Charley even though the storm was not as strong when it hit Orlando, Florida, as it had been when it struck Havana.

No information is available on damage to Havana harbor or other harbor and port facilities, but large cranes as well as warehousing facilities undoubtedly sustained damage.

Cuban government officials have reported damage to 60 industrial centers throughout the region and more than 3,127 "economic installations" in Havana Province alone but offered no additional detail. 


\section{Tourism Infrastructure}

The tourism industry represents the single largest source of hard currency earnings for the Cuban government. Given the chronic trade deficits that the Cuban government runs, the flows of funds from tourism make this industry one of the most important economic sectors for the Cuban economy. Because of its importance, some analysis of the tourist infrastructure is in order, although we by no means consider ourselves authorities on this sector of Cuba' economy.

While no specific information is yet available on damage to tourist hotels and facilities, it is speculated that infrastructure for the tourist industry may not have experienced particularly extensive damage for a number of reasons. First of all, there are relatively few tourist facilities on the southern shore of Cuba where the storm came ashore. (The resort area of Key Largo is located off Cuba's south shore, but the storm passed about 50 to 60 miles west of this island. Given the compact nature of Hurricane Charley, damage to this resort area may have been relatively minor and limited to some flooding. ) Also, most tourist hotels and facilities throughout the island are relatively new or recently substantially refurbished and thus are likely to be able to survive severe weather conditions better than older, poorly maintained structures. That said, some of the newer tourist hotels in Havana with large glass fronts and panels may well have sustained damage from high winds. Also, Cubas cruise ship passenger facility in Havana harbor could have been damaged by the hurricane.

Damage was reported to the Hemingway Marina and hotel complex on the western side of the city of Havana. No reports were found indicating a large storm surge on the northern shore of Cuba from Hurricane Charley, so flooding in this area appears to have been limited to that caused by heavy rains which appear to have been spotty in nature.

It should be noted that Cuba has numerous oil wells pumping in close proximity to the northern coastline (in some cases within about 200 feet) east of the city of Havana and near the prime resort beaches at Varadero. Any storm-related damage to these oil wells could create an ecological disaster that would be devastating for Cubas critically important tourist industry. However, to this point there have been no reports of damage to any oil wells or pumping facilities from the storm.

\section{Rural Infrastructure}

Because of the communication difficulties within Cuba following the storm and the characteristic emphasis on reporting on larger population centers, no information is available on damage to rural areas other than the statistics for homes damaged in the Havana and Pinar del Rio Provinces (as separate from the city of Havana). However, based on the extent of the damage caused in the city of Havana after the storm had been over land for about two hours, it is safe to assume that rural areas around the city and areas, which were struck earlier, suffered significant damage as well.

The Cuban press provided some support for this observation on Sunday, August 15th when they reported that "Cuban Vice President Carlos Lage called for the stepping up recovery efforts (sic) in the city of Havana so as to more quickly direct increased support to surrounding rural areas hard hit by Hurricane Charley" (Agencia Cubana de Noticias, Division de la Agencia de Información Nacional at http://www.cubaweb.cu/ingles2.htm).

\section{Agriculture}

Very little detailed information is available regarding damage to Cuba's agricultural sector from Hurricane Charley. Food supplies are a particularly important issue for the Cuban government, given the difficulties it has faced in feeding its populace even before the storm. This section will bring together what spotty information is available and attempt to speculate on the impact Hurricane Charley may have had on Cuba's various agricultural commodity and natural resource-based sub-sectors.

Agricultural production data by province in Cuba are unavailable. However, it is known that Havana Province, Pinar del Rio Province (immediately to the west of Havana Province), and Matanzas Province (immediately to the east of Havana Province) tend to be important production regions for agricultural commodities to feed the 
people in the city of Havana, Cuba's largest city with a population of about 2.2 million.

Hurricane Charley was a fairly compact storm with hurricane force winds only extending out about 30 miles from the eye. Tropical storm force winds (39 to $73 \mathrm{mph}$ ) may extend out as far as 125 miles from the eye of a hurricane, but in the case of this compact storm, it appears as though wind speeds dropped off rapidly beyond about 40 to 50 miles, so major wind damage likely was limited to a fairly narrow swath across Cuba.

Heavy rains accompanying Hurricane Charley appear to have been somewhat isolated although they are reported to have caused flooding problems in a number of areas. Soils in Cuba tend to drain fairly quickly, so except for damage that may have been caused by runoff erosion, damage to crops from rainfall may not have been particularly extensive.

The Cuban government did report damage to more than 3,000 "agricultural installations" although there was no indication of what was included in this classification. Presumably, it refers to barns, packinghouses, and storage and processing facilities. Significant damage may also have been experienced at food warehouses and storage facilities in the city of Havana and elsewhere in the affected region, resulting in losses of crops already harvested and/or processed and even on imported food products.

Effects of hurricane wind and heavy rain will vary among crops, so the following sections offer some observations for each of Cuba's major agricultural crops.

\section{Sugar}

Hurricane Charley likely caused relatively little damage to Cuba's sugar industry because the area where the storm passed is not an important sugarcane producing area (for additional information on Cuba's sugar industry go to the Sugar publications page of the Food and Resource Economics Departments website on Cuban agriculture at http://www.cubanag.ifas.ufl.edu/publications/ sugar.htm). Also, sugarcane can tolerate high winds and rain without long-term damage, although "lodging" of the cane four to five months before harvesting may represent a problem. No large sugarcane mills are in the area either, so this is probably a relatively insignificant event for the Cuban sugar industry. (Cuba's sugar industry is facing many other structural problems as indicated by the fact that total sugar production has fallen from nearly 9 million metric tons in the late 1980s to about 2.2 million metric tons today. In fact, Cuba's sugar production volumes over the past several seasons have been among the lowest in the past 70 years.)

\section{Citrus}

Because of climatic differences, Cuba's citrus ripens before Florida's, and therefore the citrus harvest for white and red grapefruit had already begun in Cuba (for additional detail on Cuba's citrus industry go to the Citrus publications page of the Food and Resource Economics Departments website on Cuban agriculture at http://www.cubanag.ifas.ufl.edu/publications/ citrus.htm). As Hurricane Charley was approaching, Cuban officials reported that farmers had accelerated their harvesting of all crops, particularly grapefruit.

Hurricane Charley did impact some citrus growing areas in Cuba, although the largest growing areas were not in the path of the storm. The Isle of Youth off Cuba's southwestern shore was the first citrus production region to be struck by the storm. This area produces almost exclusively grapefruit and was within approximately 30 miles of the eye wall of Hurricane Charley as it passed on its way to the main island and therefore experienced heavy winds from the storm. These winds undoubtedly caused significant fruit drop and likely did some tree damage as well. Before Hurricane Charley struck, citrus officials on the Isle of Youth were estimating that grapefruit losses from the storm would be approximately 15,000 metric tons (approximately 390,000 85-pound boxes).

On August 20th, the Cuban government reported that Hurricane Charley had knocked 66,000 metric tons of citrus from the trees in Havana Province. Citrus production in Havana Province is more heavily oriented toward oranges than toward grapefruit. Based upon somewhat dated statistics on the proportion of oranges versus grapefruit production in 
Havana Province, it is very roughly estimated that approximately 50,000 metric tons of the loss in Havana Province was oranges (representing about 1.2 million 90-pound boxes) and the balance of 16,000 metric tons was grapefruit (approximately 400,000 85-pound boxes).

No hard information is available on possible tree damage in either the Isle of Youth or the Havana Province, although anecdotal reports filtering into Havana from the Cuban countryside indicate substantial damage to citrus trees with many broken limbs and uprooted trees. Damage in Cuba may be comparable to the extensive damage levels experienced in citrus groves in DeSoto, Hardee, and Polk Counties in Florida.

Cuba's fresh citrus exports peaked in the early 1990s. Since that time, there has been a clear and consistent trend toward exporting smaller volumes of fresh fruit and increased volumes of juice concentrate. This trend is particularly pronounced for grapefruit.

There is a juice processing plant on the Isle of Youth operating as a joint venture between the Cuban government and a Panamanian firm by the name of Grupo BM with Israeli principals. Hurricane Charley may well have done some damage to this processing plant, but no information is available on the nature or the extent of damage.

There is a juice processing plant in eastern Pinar del Rio Province operating as a joint venture in cooperation with an Italian company. While this plant was located far enough west of the path of the storm that it likely avoided any major storm damage, the aforementioned reported shutdown of the entire electrical power grid in Pinar del Rio Province would take this plant out of operation. Furthermore, since it would be a large consumer of power, the Cuban government may choose to keep it offline until such time as the majority of residential consumers have power restored and power-generating facilities are operating closer to capacity.

If damage to these juice processing plants was not too severe and if they have electrical power, it would be possible to recover some of the ripe citrus that was blown off the trees by the storm if the fruit could be picked up and transported to the plant and processed within a matter of a few days. Since the plant in Pinar del Rio likely did not have power in the days following the storm, recovered fruit could have been transported to more distant juice processing facilities. (It would not be physically or economically feasible to transport fruit from the Isle of Youth to processing facilities on the main island of Cuba.) However, in reality, given all of the other problems being faced by the government following the storm and the inherent inefficiencies of Cuba's planned economic system, none of this fruit is likely to have been recovered for commercial use.

Also, power outages at processing plants imply the loss of refrigerated juice concentrate inventories on hand as well.

These citrus losses are notable for Cuba because of the lost revenues to the government from the decreased volume of citrus juice and fresh citrus for export. At the very best it will be one year before Cuba's juice and fresh citrus exports are able to recover. However, to the extent that the trees are damaged, recovery in production will take longer.

Given current world citrus production levels and juice inventories, these losses are not significant in the context of the world citrus market.

\section{Tropical Fruit}

Tropical fruit tree crops are among the most vulnerable crops to hurricane damage. Bananas and plantains are particularly susceptible to damage from high winds, and agricultural workers in Cuba reportedly were hurrying to harvest these crops as the hurricane was approaching. Following the storm, reports indicate that entire banana fields were leveled and that nearly all of the banana and plantain production in Havana Province may have been wiped out. However, in most cases, these trees will sprout again from the base and be back in production relatively quickly.

The situation is far different for crops like avocado, mango, papaya, and other tropical tree fruits. For these crops, not only can fruit easily be knocked off the trees (as was the case with citrus discussed earlier), but these crops are often even 
more perishable than citrus fruit, so they deteriorate more quickly once they are blown off the tree. Also, tree branches can be broken and, with their large canopy, entire trees can be snapped off or blown over by hurricane winds, with their root system dislodged from the soil. In nearly all cases, this destroys the root system, killing the trees and, unlike bananas, these trees will take many years to grow to their previous size and productive capacity. Anecdotal reports from Havana indicated that such tree losses were indeed suffered.

Losses to tropical fruit crops in the path of the storm are very likely to have been substantial. Given the reported sustained winds of over $100 \mathrm{mph}$, almost all of the fruit on-tree in areas near the eye of the storm was probably knocked off and tree damage almost certainly was significant. It is speculated that this trail of destruction may well extend out for 40 miles or more on either side of the path of the eye of the hurricane.

While no detailed quantitative information is available on the extent of the losses to the tropical fruit industry, press reports have indicated that Hurricane Charley destroyed 740 acres of tree plantations near the city of Havana and flattened another 56,800 acres of bananas, citrus, and other fruit elsewhere in Havana Province.

\section{Vegetable Crops and Roots and Tubers}

No reports are available on damage to general food crops from Hurricane Charley. However, Havana Province is a particularly important production region for vegetable crops and roots and tubers (representing about 20 percent of total national acreage) to supply the food demands in the city of Havana. Given the extensive damage that appears to have taken place in Cuba's citrus industry from hurricane winds, the damage to vegetable crops from the storm likely was substantial as well.

Press reports from Cuba indicated that as Hurricane Charley was approaching the island, farmers were attempting to harvest their crops in an effort to minimize storm losses. Specifically mentioned in the reports were citrus (as discussed previously) and root and tuber crops.
Roots and tubers make up an important part of the Cuban diet. These include potatoes, as well as less-traditional (to the U.S. palate) crops such as yuca (cassava), boniato, and malanga (cocoyam). Root and tuber crops are particularly vulnerable to heavy rains that can saturate the soil and create disease damage and substantial losses. However, inasmuch as the torrential rains from the storm only were experienced in isolated areas, it may be that immature root and tuber crops that were not harvested did not sustain appreciable damage. On the other hand, much of the vegetative top growth of these plants may have been damaged, limiting the health and viability of the plants. Also, as extensive as storm damage to buildings and structures appears to be, storage buildings where harvested root and tuber crops were stored may well have sustained substantial damage, thus jeopardizing these inventories as well.

Inasmuch as vegetables and roots and tubers are fairly short-cycle crops, it would not take too long to replace the lost production, assuming that seed and/or propagative material is available. However, there likely will be shortages in the very short term while these crops are replanted. Also, inputs of all types are in short supply in Cuba, so there may well be some constraints that farmers will face in this recovery process.

Notably, one report from the Cuban press quotes Cuban President Fidel Castro as saying "precautionary measures taken will help minimize the destructive consequences of the storm [including] the protection of greenhouses crucial for producing vegetables for national consumption and the tourist sector. These structures were quickly disassembled but can be set up again in just a few days" (Agencia Cubana de Noticias, Division de la Agencia de Información Nacional at http://www.ain.cubaweb.cu/english/ ago13iggerngish04.htm).

\section{Livestock, Dairy, and Poultry}

The area where Hurricane Charley struck is not one of Cuba's important livestock grazing regions. However, there are a number of dairy operations in this part of the island because of its proximity to Cuba's largest city, since locating dairy operations near major population centers helps to minimize 
transportation logistics and spoilage of the product, which is a significant problem given Cuba's notoriously inefficient Acopio food collection and redistribution system. A Cuban government report on August 20th indicated that, in fact, 280 milking sheds lost their roofs or sustained other damage from Hurricane Charley. The extent of the "other damage" to these facilities, however, was not detailed, so there is no indication of to what degree or for how long milk production might be impacted.

There are acute shortages of milk and dairy products in Cuba, so these products are rationed at low levels to only children and the elderly, and they are very important sources of nutrition to these population groups. Damage to the dairy industry facilities in Cuba will undoubtedly affect milk production in the short term and place pressure on the Cuban government to find other ways to provide milk to the aforementioned segments of the population.

Reports from the Cuban press indicate that nearly 160,000 head of livestock were moved from low-lying and flood-prone areas. Except for threats from flooding, livestock typically fare reasonably well in heavy storms. There are no reports of livestock lost and it is unlikely that there were any significant losses in livestock due to the Hurricane.

Given the extensive damage to milking sheds, the impact on Cuba's poultry industry is another important consideration, since poultry houses are typically constructed in a manner that makes them susceptible to storm damage. Since the 1980s, the Cuban government has placed a higher priority on egg production than on broiler production. Eggs are an important source of protein in the Cuban diet although supplies are limited.

Statistics on poultry and egg production by province in Cuba are unavailable. However, a number of poultry operations are located in Havana Province-presumably in an effort to supply the city of Havana while minimizing transportation difficulties and perishability losses, as was the case for dairy discussed previously. No reports have been received regarding damage to the poultry industry, but it is expected to have been significant in Havana Province to the point where a notable proportion of the commercial bird population in the region may have been lost either from injuries incurred as poultry houses were collapsing or as they escaped from damaged houses.

\section{Marine and Seafood Products}

The town of Batabanó on the southern coast of Cuba, near where the eye of Hurricane Charley came ashore, is one of Cuba's most important processing centers for spiny lobster and finfish and is the nerve center for Cuba's sponge industry. Because of the increasing importance of these products as generators of export revenues, the industries tend to be quite well-organized (by Cuban standards). Fishing boats supporting these industries presumably were moved to safety. However, most of the processing facilities are located on or near the coast and the storm surge created by Hurricane Charley is reported to have been as high as 15 to 20 feet in this area. Therefore, it is expected that damage to these facilities likely was very significant. It is expected that this will significantly curtail Cuban exports of these products in the near to medium term, constraining hard currency earnings and detrimentally impacting the financial situation faced by the Cuban government.

\section{Forestry}

According to the Cuban press, Hurricane Charley is reported to have brought down an estimated 8,000 trees in the city of Havana alone. Losses elsewhere in the path of the storm presumably were significant, although no information on storm damage to the commercial forests or forest reserves of Cuba has been forthcoming. Statistics on forestry production by province are unavailable, but reports indicate that Havana Province is not one of Cuba's important regions for forestry production or forest reserves. Conversely, published work reports that Pinar del Rio Province has Cuba's largest acreage of forest reserves. Travel through the eastern portions of Pinar del Rio Province and anecdotal reports suggest that the largest forested areas are not in the eastern part of the province along the border with Havana Province. For that reason, storm damage to commercial forests and forest reserves in Cuba from Hurricane Charley is expected to have been minor. 


\section{Summary and Conclusions}

Based on the information presented in this briefing, some short-term food shortages in Cuba may be expected as a result of damage to the agricultural sector and related infrastructure from Hurricane Charley. The shortages would most likely be experienced in the city of Havana with its population of over two million. However, extensive outages of electrical power, water and gas experienced by Havana residents following the storm likely have raised tensions and tempers in the city. For that reason, the Cuban government may choose to divert food supplies from other regions of the country in an effort to keep food shortages from becoming yet another source of frustration for the citizens of the city of Havana.

These shortages could be alleviated to a certain extent by increased imports of food and agricultural products. Such imports could come from any of Cuba's trading partners, but Cuba's payment record is so poor that few countries or companies are likely to extend additional credit to Cuba for new purchases. Some of the imports could come from emergency food aid from other nations, but no reports of such aid have been found.

The relatively immediate need for increased food supplies would suggest that the United States would be an important potential supplier because of its proximity and the short transit times for delivery of food products. However, since U.S. regulations require cash payment for all purchases by Cuba, the question arises as to whether the Cuban government can afford to pay cash for these increased purchases. The Cuban government may have small reserves for such purchases, but Cuba's persistent balance of payments deficits and other macroeconomic problems suggest that these reserves are probably quite limited.

No press reports have been found indicating an appreciable jump in U.S. food and agricultural exports to Cuba and the official U.S. government reports of shipments that might reflect increases in purchases since the storm are not yet available.

Potential storm damage to the port of Havana would not be expected to be a particularly important constraint since there are other ports in the region that likely could handle the shipments, although the more distant they are from Havana, the higher the transportation costs and the more difficult the logistics faced by the Cuban government.

The extensive damage to buildings in and around the city of Havana suggests that agricultural and food storage facilities throughout the affected area also sustained damage. This is expected to result in losses of stored food products, thus further exacerbating the problems being faced in feeding the population.

All of this said, no reports have been forthcoming regarding food shortages in Cuba.

Another consideration is the issue of the impact of Hurricane Charley on Cuba's foreign currency flows. Cuba's exports of shellfish and citrus products undoubtedly will be reduced in the short term from storm damage. In fact, shellfish processing facilities probably will take quite a bit of time to be rebuilt and this could limit exports into the medium term. The amount of damage sustained at the juice processing facility on Cuba's Isle of Youth will greatly influence Cuba's productive capabilities although, realistically, there may not be enough grapefruit remaining on the trees on the Isle of Youth for this to be a pressing issue. The level of damage to Cuba's citrus trees is not known; some tree damage was almost certainly sustained and this will detrimentally impact fresh and processed citrus exports in the medium term. These short- and medium-term losses in export revenues are problematic for the Cuban government.

Physical damage to the tourist industry infrastructure in Cuba from Hurricane Charley is likely to be fairly limited. Furthermore, the active involvement of a number of European and Canadian firms in joint venture partnerships with the Cuban government at many resort hotels on the island suggests that investment funds necessary for repair and recovery from the storm will be more readily available than if the Cuban government had to provide such funding. For these reasons, the impact of the storm on the tourist industry may be fairly short term in nature. Summer is the slow season for Cuba's tourism industry, and by fall, Cuba's European and Canadian joint venture partners should be able to make any necessary repairs and mount promotional 
campaigns to assure potential tourists that Cuba has recovered from the storm so that they will be able to fully enjoy their vacation. Nevertheless, any slowing of the inflows of foreign capital from tourism in the coming months places yet more pressure on the Cuban government's already strained finances. 